\title{
Characterization and Utilization of Sulphuric Acid and Bitter Leaf Extract Activated Carbon from Rice Husk for Zn(II) Adsorption
}

\author{
Ilesanmi Osasona* and Ujiro Bestow Kanuhor
}

Department of Chemical Sciences, Afe Babalola University, Km 8.5, Afe Babalola Way, P.M.B. 5454, Ado-Ekiti, Nigeria

*Corresponding author:

tel: $+234-8030656679$

email:oosasona@yahoo.com

Received: March 10, 2020

Accepted: October 9, 2020

DOI: $10.22146 / \mathrm{ijc} .54786$

\begin{abstract}
The world is clamoring for green synthetic modes of scientific and technological operations. From this point of view, an attempt was made to prepare activated carbon from rice husk using aqueous bitter leaf extract and a mineral acid $\left(\mathrm{H}_{2} \mathrm{SO}_{4}\right)$ separately. The surface characteristics and the adsorption properties of the activated carbons from both methods were compared. The effects of adsorption variables on the adsorption of $\mathrm{Zn}(\mathrm{II})$ by bitter leaf extract activated carbon (RHAC1) and $\mathrm{H}_{2} \mathrm{SO}_{4}$ activated carbon (RHAC2) were conducted through batch studies. The morphological characterization revealed RHAC1 to be fibrous, more porous and contained finer particles than the chemical-activated counterpart. The role of hydroxyl and carbonyl groups in the adsorption of $\mathrm{Zn}(\mathrm{II})$ was pivotal. The optimum $\mathrm{pH}$ values for the adsorption of $\mathrm{Zn}$ (II) by both samples was 7. The adsorption kinetics and equilibrium isotherm obeyed Elovich and Freundlich models respectively while the evaluated Langmuir $q_{\max }$ were 71.47 and $67.12 \mathrm{mg} \mathrm{g}^{-1}$ for RHAC1 and RHAC2 respectively. The thermodynamic parameters revealed that the process was endothermic and spontaneous at all evaluated temperatures. Therefore, bitter leaf aqueous extract, as an activating agent for carbon production, could serve as a better or close substitute for the less environment-friendly $\mathrm{H}_{2} \mathrm{SO}_{4}$.
\end{abstract}

Keywords: adsorption; green synthesis; rice husk; bitter leaf; activated carbon

\section{- INTRODUCTION}

Advances in global technology and knowledge have their inherent merits and demerits. Of course, the advantages derivable from technological advancement outweigh its disadvantages, yet technologies involving the use of chemicals, metals, and metalloids have grave consequences on the sustainability of the environment. An unhealthy environment will breed unhealthy life. Hence, to maintain the sustainability of the global environment, the influx of pollutants must be controlled. Water is a major component of our physical environment that contributes greatly to life sustenance. However, its life-sustaining ability is constantly being threatened as a result of the introduction of harmful substances through various human technological endeavors [1]. The chief among these harmful substances are heavy metals contained in industrial wastewater. Some heavy metals commonly contained in industrial wastewater include: lead, chromium, mercury, uranium, selenium, zinc, arsenic, cadmium, silver, gold, and nickel [2].

Zinc belongs to the Group IIB elements alongside the highly toxic cadmium and mercury. It is a trace element known to play a key role in human health. It is important for the physiological functions of living tissues and regulates many biochemical processes. $\mathrm{Zn}$ (II) is involved in the function of enzymes in several different areas of metabolism. For example, enzymes involved in carbohydrate and energy metabolism, acid/base balance, protein biosynthesis and degradation, nucleic acid biosynthesis, cellular protection against free radicals (superoxide dismutase), inter-conversion of trans-retinal with retinol, heme biosynthesis, dihydrotestosterone production, and several other reactions that are reported to be associated with zinc [3-4]. In spite of its important biochemical roles in the human body, excessive ingestion of zinc, can bring about serious health problems, which include stomach cramps, abdominal 
pains, skin irritations, vomiting, nausea, and anemia [5-6]. There are three major ways a man can be exposed to zinc: through inhalation, through the skin, or by ingestion [6].

To avoid excessive exposure/intake and concomitant accumulation of zinc in the human body, the need to reduce the concentration of zinc present in wastewater becomes imperative. To achieve this, many conventional methods are available to remove heavy metal ions from industrial effluents. Among these methods are: the use of chemical precipitation, crystallization, reverse osmosis, electrophoresis, coagulation, floatation, ultrafiltration, ion exchange, etc. [3,7]. All these methods are associated with different drawbacks such as: sludge production, high cost of operation, ineffectiveness/poor efficiency at low metal concentration, etc. Adsorption, particularly using commercial activated carbon (CAC) is a better alternative to heavy metal sequestration from wastewater [8-9]. However, the use of CAC is constrained by high cost and requirement of chelating agent to increase its performance which definitely increases its cost of operation [10].

The high cost associated with the use of commercial activated carbon gave birth to the search for less expensive and better efficient alternatives. To this end, researchers have beamed their searchlight on the production of activated carbon from cheap and readily available materials. The use of activated carbons from various precursors has been reported for heavy metals removal. Among these are activated carbon from: spent barley husks [11], Spartina alterniflora [12], almond husk [13], apricot stones [14], activated coconut shell [15], etc. In particular, some of the precursors that have been exploited for $\mathrm{Zn}$ (II) removal are activated carbon from: mesembryanthemum [16], olive stone [17], bamboo [18], Xanthoceras sorbifolia bunge hull [19], eucalyptus seeds [20], olive branches [21], saw dust [22], oil palm mill effluent [23], etc.

Rice husk is a fibrous agricultural by-product obtained from the rice paddy processing after harvest. Rice processing involves several steps: removal of the husks, milling the shelled rice to remove the bran, and an additional whitening step to meet market expectations for the appearance of the rice kernels. This process leads to the generation of different by-products which include: husks, bran, and milled rice kernel [24]. Rice husk forms about $16-25 \%$ by weight of the paddy processed [25]. Heaps of rice husks can be sited around different rice mills in Nigeria.

Nigeria annually generates about 1.1 million tons out of about 120 million tons of rice husk generated globally [25-26]. Rice husk disposal constitutes a great environmental threat to the surroundings of the milling houses. The major disposal method for rice husk is combustion which also constitutes greater environmental pollution. Hence, recycling this agricultural waste and converting it to high-value material is not only beneficial to the environment but also a promising bio-resource technology [27].

Vernonia amygdalina, commonly called bitter leaf because of its bitter taste is a shrub growing to a height of 3 or more meters in the African tropics and other parts of Africa, particularly, Nigeria, Cameroon, and Zimbabwe [28]. The leaves are consumed either as a vegetable (macerated leaves in soup) or aqueous extracts as tonics for the treatment of various illnesses such as anemia, nausea, diabetes, loss of appetite, dysentery, gingivitis, toothache, and gastrointestinal tract problems [29-30]. The biologically-active compounds which have been extracted and isolated from Vernonia amygdalina are: saponins and alkaloids, terpenes, steroids, coumarins, flavonoids, phenolic acids, lignans, xanthones, and anthraquinone, edotides, and sesquiterpenes [28]. The presence of these phytochemicals in Vernonia amygdalina could be exploited as activating agents in the production of activated carbon since the phytochemicals, particularly the flavonoids and phenolic compounds, are known for metal chelating activities and redox reactions [31].

Therefore, this study was conducted to compare the adsorptive properties of bitter leaf extract activated carbon (RHAC1) and $\mathrm{H}_{2} \mathrm{SO}_{4}$ activated carbon (RHAC2) from rice husk for the removal of $\mathrm{Zn}$ (II) from aqueous solution. From extensive literature search, no report has been made on the use of plant-derived acids or extracts for the activation or modification of carbons for adsorption purposes. Generally, chemical and physical activation methods that are rather non-eco-friendly and/or expensive to operate and maintain have been 
used for a very long time. This study is an attempt to make the environment safer for both humans and animals.

\section{- EXPERIMENTAL SECTION}

\section{Materials}

Chemicals and reagents used include: sulphuric acid $\left(\mathrm{H}_{2} \mathrm{SO}_{4}\right)$, zinc sulphate heptahydrate $\left(\mathrm{ZnSO}_{4} \cdot 7 \mathrm{H}_{2} \mathrm{O}\right)$, hydrochloric acid $(\mathrm{HCl})$, sodium hydroxide $(\mathrm{NaOH})$ and potassium hydroxide $(\mathrm{KOH})$. All reagents were of analytical grade, hence no further purification was carried out before use.

\section{Procedure}

\section{Collection and preparation of materials}

Rice husk was collected from a local rice mill industry in Ado-Ekiti, Ekiti State, Nigeria. The husk was thoroughly washed with distilled water and oven-dried at $105^{\circ} \mathrm{C}$ to a constant weight. The dried husks were stored in desiccators to avoid exposure to atmospheric moisture and transferred into a well-sealed and air-tight container in preparation for carbonization and activation. Bitter leaves (Vernonia amygdalina) were plucked from Afe Babalola University's farm. The leaves were authenticated at the Department of Plant Science, Ekiti State University, Ado-Ekiti, Ekiti State, Nigeria. The leaves were thoroughly washed with distilled water to remove dirt and dust particles. Then the leaves were blended with the addition of $5 \mathrm{~mL}$ of distilled water per $10 \mathrm{~g}$ of leaves. The aliquot was filtered using a mesh net and the filtrate was collected. The rice husk was carbonized using a muffle furnace (Vecstar Ltd England) which allows little supply of air. Carbonization was done at $350{ }^{\circ} \mathrm{C}$ for $30 \mathrm{~min}$. The carbonized sample was then allowed to cool in a desiccator at room temperature [32].

\section{Chemical and bio-activation of carbonized rice husk}

The carbonized rice husk was activated using the method described by Osasona et al. [11]. Twenty-five grams of carbonized rice husk $(425 \mu \mathrm{m})$ was weighed into a beaker containing $500 \mathrm{~mL} 0.1 \mathrm{M}$ sulphuric acid. The contents of the beaker were thoroughly mixed and heated at $60^{\circ} \mathrm{C}$ on a magnetic stirrer with a hot plate until a paste was formed. The paste was transferred to an evaporating dish which was placed in a furnace and heated at $500{ }^{\circ} \mathrm{C}$ for $30 \mathrm{~min}$. The sample was then allowed to cool overnight. It was then neutralized with $\mathrm{KOH}$ and washed several times with distilled water until the $\mathrm{pH}$ was $6.80 \pm$ 0.1 . The sample was further oven-dried at $105{ }^{\circ} \mathrm{C}$ to a constant weight and was kept in an air-tight bottle. Twelve and a half grams ( $12.5 \mathrm{~g})$ of $\mathrm{RH}$ was soaked in $250 \mathrm{~mL}$ of Vernonia amygdalina extract with intermittent shaking for $12 \mathrm{~h}$. The mixture was then filtered using a mesh net and washed with distilled water several times. The residue was oven-dried at $105{ }^{\circ} \mathrm{C}$ for $1 \mathrm{~h}$ to obtain the carbonized rice bran treated with Vernonia amygdalina. The dried residue was then stored in an airtight container. The bitter leaf extract activated carbon from rice husk was subsequently referred to as RHAC1 while its acid-activated counterpart was tagged as RHAC2.

\section{Characterization of activated carbons from rice husk}

The activated carbon samples from rice husk were characterized using Fourier Transform-Infrared Spectroscopy (FTIR), Scanning Electron Microscope (SEM), and Energy Dispersion X-Ray (EDX). FT-IR analysis in solid phase was performed on the samples before and after zinc adsorption at the central research laboratory of Ladoke Akintola University of Technology, Ogbomoso, Oyo State, Nigeria using Fourier Transform Infrared Spectrometer (Shimadzu 100 series spectrometer USA). This analysis was conducted to determine the possible involvement of the surface functional groups on the $\mathrm{RH}$ surface in the adsorption process. Five milligrams (5 mg) of each sample was homogenously mixed with dry potassium bromide and made into pellets in a disc by applying pressure. The spectra of the adsorbents were measured within the wavenumber range of 4000$400 \mathrm{~cm}^{-1}$. The spectra were plotted using the same scale on the transmittance axis for all the adsorbents before and after adsorption. The qualitative and quantitative elemental composition and the morphology of the different activated carbons from rice husk were determined in the Geology laboratory, University of Ibadan, Nigeria using SEM-EDX couple (JEOL JSM7600F). 


\section{Procedure for batch studies}

Unless otherwise stated, all experimental runs were carried out in $100 \mathrm{~mL}$ conical flasks for $60 \mathrm{~min}$ at room temperature. Forty milliliters $(40 \mathrm{~mL})$ of $25 \mathrm{mg} \mathrm{L}^{-1} \mathrm{Zn}$ solution prepared from a stock solution of $\mathrm{ZnSO}_{4} \cdot 7 \mathrm{H}_{2} \mathrm{O}$ (prepared by dissolving $4.42 \mathrm{~g}$ of analytical grade $\mathrm{ZnSO}_{4} \cdot 7 \mathrm{H}_{2} \mathrm{O}$ with distilled water in a $1 \mathrm{~L}$ standard flask) was agitated with $0.1 \mathrm{~g}$ activated carbon from rice husk on a SearchTech Instrument SHZ-82 Thermostatic water bath shaker (India) operated at a steady speed. The mixture of the activated carbon and $\mathrm{Zn}$ (II) solution was filtered using filter paper after agitation and the concentration of residual $\mathrm{Zn}$ (II) in the filtrate was determined using Atomic Absorption Spectrometer (Buck Scientific 210 VGP).

Experiments on the variation of $\mathrm{pH}$ were conducted by adjusting the $\mathrm{pH}$ of different standard solutions (each containing $25 \mathrm{mg} \mathrm{L}^{-1} \mathrm{Zn}$ ) from $\mathrm{pH}$ of 2 to 7 using $0.1 \mathrm{M}$ $\mathrm{HCl}$ or $0.1 \mathrm{M} \mathrm{NaOH}$. Subsequent experiments were conducted at the optimum $\mathrm{pH}$ obtained from the experiment on $\mathrm{pH}$ variation. The effect of contact time was determined by varying the agitation time from 5 to $240 \mathrm{~min}$. Temperatures of $298,303,313$, and $323 \mathrm{~K}$ were used to determine the effect of temperature while the activated carbon dosage range of $0.05-0.25 \mathrm{~g}$ was employed to determine the effect of adsorbent dosage on $\mathrm{Zn}$ (II) adsorption. Equilibrium isotherm studies were conducted by varying the initial metal concentration from 5 to $100 \mathrm{mg} \mathrm{L}^{-1}$ at $298 \mathrm{~K}$.

The amount of zinc adsorbed per unit mass $\left(\mathrm{q}_{\mathrm{e}}\right)$ of activated carbon was determined using the following equation:

$\mathrm{q}_{\mathrm{e}}=\left(\frac{\mathrm{C}_{\mathrm{f}}-\mathrm{C}_{\mathrm{i}}}{\mathrm{m}}\right) \mathrm{V}$

Where; $\mathrm{m}$ is the mass of activated carbon used $(\mathrm{g}), \mathrm{V}$ is the volume of the solution $(\mathrm{L}), \mathrm{C}_{\mathrm{i}}$ is the initial concentration of $\mathrm{Zn}\left(\mathrm{mg} \mathrm{L}^{-1}\right)$ and $\mathrm{C}_{\mathrm{f}}$ is the equilibrium concentration of $\mathrm{Zn}(\mathrm{II})\left(\mathrm{mg} \mathrm{L}^{-1}\right)$ in the filtrate.

The removal efficiency (\%R) of each activated carbon was calculated using the following expression:

$\% \mathrm{R}=\frac{\left(\mathrm{C}_{\mathrm{o}}-\mathrm{C}_{\mathrm{f}}\right) \times 100}{\mathrm{C}_{\mathrm{o}}}$

\section{- RESULTS AND DISCUSSION}

\section{Effect of $\mathrm{pH}$}

The effect of $\mathrm{pH}$ is the most important parameter affecting adsorption from aqueous medium because it affects the solution chemistry of metals and the functional groups on the adsorbent surface [33-34]. The result of the experiments on the effect of $\mathrm{pH}$ on the adsorption of $\mathrm{Zn}$ (II) by activated carbon from rice husk is shown in Fig. 1. It was observed that the increase in $\mathrm{pH}$ brought about an increase in the percentage of zinc removed. The percentage removal (\%R) of $\mathrm{Zn}(\mathrm{II})$ increased from $31.2 \%$ to $98.96 \%$ for RHAC1 (bitter leaf extract activated carbon) and from $18 \%$ to $93.60 \%$ for RHAC2 $\left(\mathrm{H}_{2} \mathrm{SO}_{4}\right.$ activated carbon) when the $\mathrm{pH}$ was increased from 2 to 7 . This tends to happen because at low $\mathrm{pH}$ values, the activated carbon surface is saturated with hydrogen ions, thereby decreasing the percentage of $\mathrm{Zn}$ (II) adsorbed because of the electrostatic repulsion existing between the two cations. In addition, the $\mathrm{H}^{+}$ ions in the solution compete with $\mathrm{Zn}$ (II) ions for the active sites on the adsorbent. By increasing the $\mathrm{pH}$, the number of $\mathrm{H}^{+}$ions will be reduced: the competition between $\mathrm{H}^{+}$ions and $\mathrm{Zn}$ (II) for adsorption sites will also be decreased. It is a common phenomenon to observe that the surfaces of adsorbents adsorb cations poorly at low $\mathrm{pH}$ values due to the presence of $\mathrm{H}^{+}$ions, whereas,

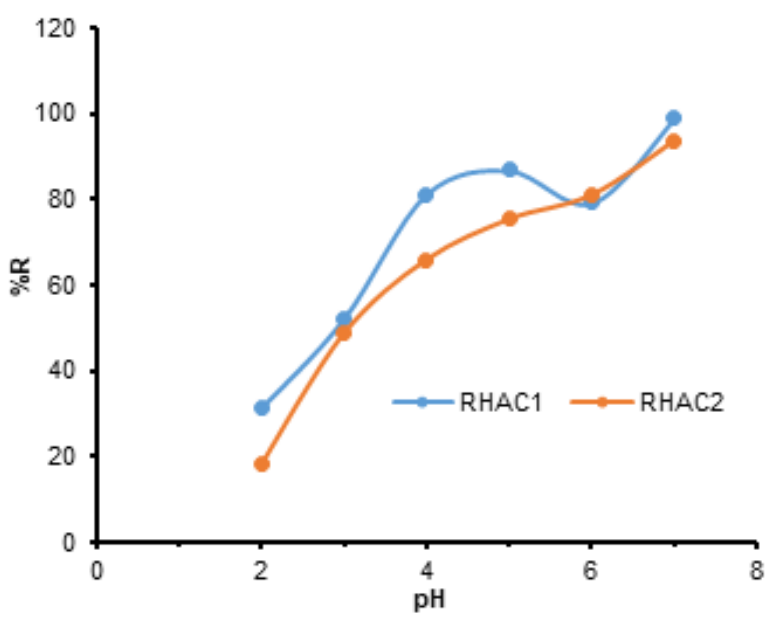

Fig 1. Effect of $\mathrm{pH}$ on the adsorption of $\mathrm{Zn}$ (II) using RHAC1 and RHAC2 
adsorbent surfaces actively adsorb cations at high $\mathrm{pH}$ values due to the high concentrations of $\mathrm{OH}^{-}$ions [35]. It is obvious from Fig. 1 that the adsorption of $\mathrm{Zn}$ (II) by RHAC1 was slightly higher than that by RHAC2. The optimum $\mathrm{pH}$ level of adsorption was found to be 7 for both RHAC1 and RHAC2. Previous studies have also reported the $\mathrm{pH}$ range of 6-7 as the optimum condition for $\mathrm{Zn}$ (II) adsorption by activated carbon from different precursors [17,36-39]. However, some authors have also reported the $\mathrm{pH}$ range of 4-5 as the optimum condition for $\mathrm{Zn}$ (II) removal by certain activated carbons [19-22]. Further experiments were carried out at the optimum $\mathrm{pH}$ of adsorption for each of the activated carbon samples.

\section{Effect of Contact Time}

Fig. 2 presents the result of the effect of agitation time on the adsorption of $\mathrm{Zn}$ (II) by RHAC1 and RHAC2. The figure reveals that the adsorption of $\mathrm{Zn}$ (II) was rapid at the initial stage of the contact period, and thereafter became slower near the equilibrium. This is because at the initial stages, the ratio of the unoccupied adsorbent sites to the number of adsorbate particles is higher than at the later stages. This is obvious from the fact that a large number of vacant surface sites are available for adsorption during the initial stage. However, the remaining vacant surface sites are difficult to be occupied due to repulsive forces between the solute molecules on the solid and solution phases [35].

For both RHAC1 and RHAC2, the rate of $\mathrm{Zn}$ (II) adsorption was very rapid within the first $5 \mathrm{~min}$ of equilibration. The adsorption rate for RHAC1 proceeded gradually after this rapid stage to attain equilibrium after 30 min while the adsorption rate for RHAC2 passed through a steady increase stage between the agitation period of 10 and $60 \mathrm{~min}$ before proceeding to equilibrium.

\section{Effect of RHAC1 and RHAC2 Dosage}

The effect of activated carbon dosage on the adsorption of $\mathrm{Zn}(\mathrm{II})$ is depicted in Fig. 3. It is clear from the figure that the percentage removal of $\mathrm{Zn}$ (II) by RHAC1 and RHAC 2 increased with the increase in the mass of the activated carbon. This is expected because as the amount of carbon dose increases, the number of surface active sites for $\mathrm{Zn}$ (II) adsorption also increases.

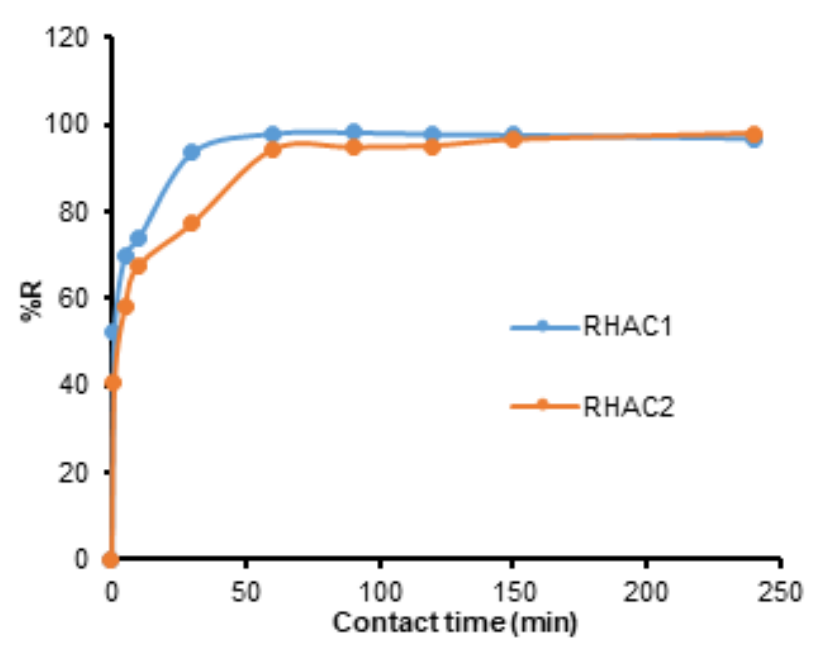

Fig 2. Effect of contact time on the adsorption of $\mathrm{Zn}(\mathrm{II})$ from aqueous solution using RHAC1 and RHAC2

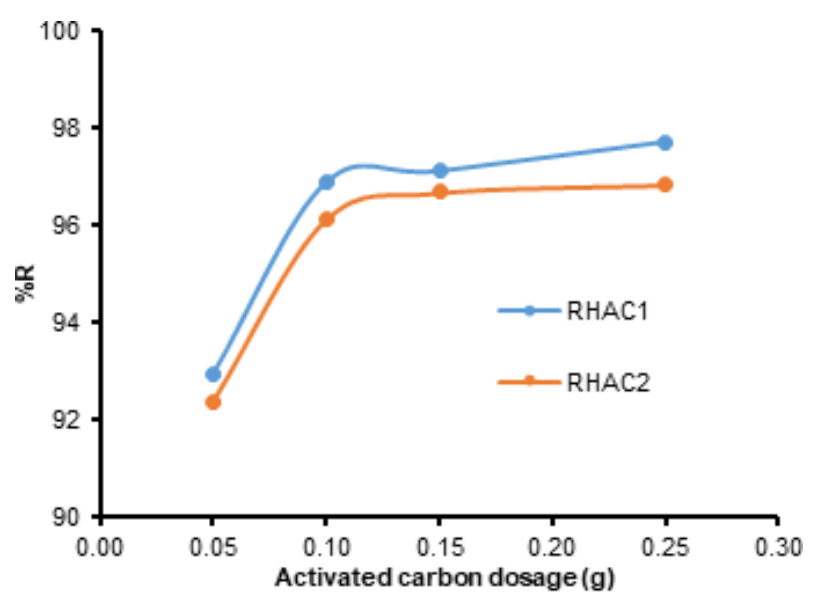

Fig 3. Effect of adsorbent dosage on the adsorption of $\mathrm{Zn}$ (II) from aqueous solution using RHAC1 and RHAC2

\section{Characterization}

Activated carbon is generally described as an amorphous form of graphite with a random structure of graphite plates; having a highly porous structure with a range of cracks and crevices reaching molecular dimensions [35]. The SEM micrographs of the inactivated carbons, RHAC1 and RHAC2, before and after Zn(II) adsorption are shown in Fig. 4. The figure presents both RHAC1 and RHAC2 as porous materials having different morphological appearances. The bitter leaf activated carbon (RHAC1) appeared to be fibrous, more porous and contained finer particles than RHAC2. The number of pores in RHAC1 was found to be relatively 

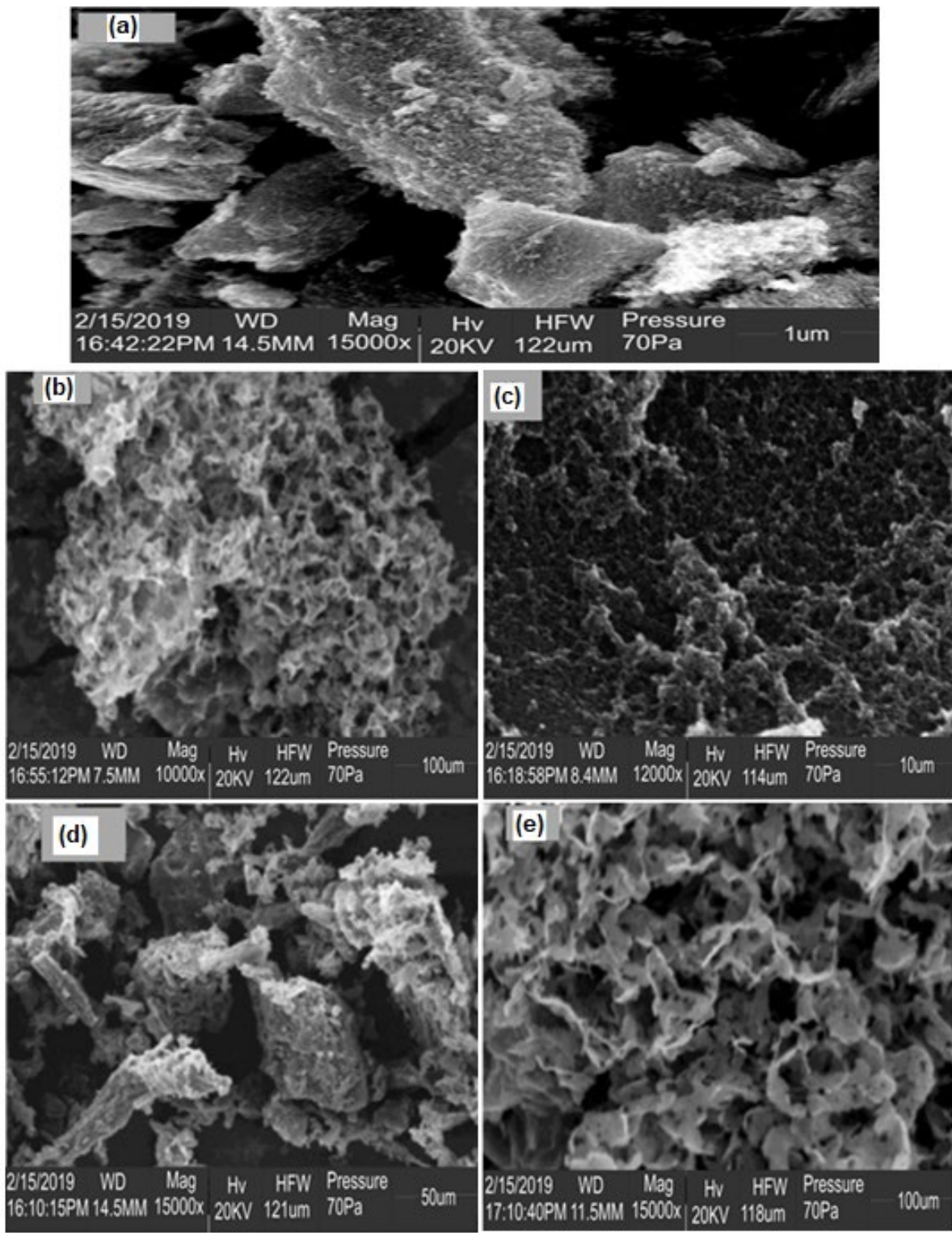

Fig 4. SEM micrographs of: inactivated carbonized rice husk (a), RHAC1 before (b) and after Zn adsorption (c); RHAC2 before (d) and after Zn(II) adsorption (e)

greater than that of RHAC2. Comparing the morphological characteristic of the samples, both bitter leaf (Fig. 4(b)) and $\mathrm{H}_{2} \mathrm{SO}_{4}$ activated (Fig. 4(d)) samples were more porous than the inactivated sample (Fig. 4(a)). In addition, the inactivated sample appeared in flaky layers while the bitter leaf and $\mathrm{H}_{2} \mathrm{SO}_{4}$ activated variants were fibrous and porous. It is obvious that the number of pores on the surfaces of both RHAC1 and RHAC2 seemed to decrease after $\mathrm{Zn}$ (II) adsorption (Fig. 4(c) and 4(e)). The reduction in the number of pores can be attributed to the adsorption of $\mathrm{Zn}(\mathrm{II})$ ions on the activated carbon surfaces.

Fig. 5 presents the EDX results of the inactivated carbon, RHAC1 and RHAC2 before and after $\mathrm{Zn}$ (II) adsorption. It is apparent from the figure that RHAC1 and RHAC2 are carbonaceous. In addition, EDX analysis shows that $\mathrm{Zn}$ formed part of the elemental components of both RHAC1 and RHAC2 after adsorption.

In order to determine the possible involvement of functional groups in the adsorption of $\mathrm{Zn}$ (II) by RHAC1 
and RHAC2, the FTIR analyses of the samples were conducted and the results are presented in Fig. 6 and 7. The peaks at 3537, 3449, 3274 and $3219 \mathrm{~cm}^{-1}$ (Fig. 6(a)), recorded for carbonized rice, which are due to the hydroxyl group with hydrogen bonding of $\mathrm{OH}$ stretching vibration were respectively shifted to $3536,3458,3276$ and $3223 \mathrm{~cm}^{-1}$ (Fig. 6(b)) after bio-activation with bitter leaf extract. The same set of bands were respectively shifted to $3522,3443,3305$, and $3253 \mathrm{~cm}^{-1}$ (Fig. 7(b)) after activation of rice husk carbon with $\mathrm{H}_{2} \mathrm{SO}_{4}$. The absorption band at $3095.2 \mathrm{~cm}^{-1}$ for inactivated carbon (Fig. 6(a)) which could be assigned to $\mathrm{C}-\mathrm{H}$ stretching vibration of the methylene group disappeared after activation with bitter leaf extract (Fig. 6(b)). The same band was found to be reduced to $3013 \mathrm{~cm}^{-1}$ after activation with the mineral acid (Fig. 7(b)). The peak at $2887 \mathrm{~cm}^{-1}$, assigned to $\mathrm{C}-\mathrm{H}$ stretching of the methyl group, which was slightly decreased to $2882 \mathrm{~cm}^{-1}$ after chemical activation remained unchanged after bio-activation. The absorption band at $1660 \mathrm{~cm}^{-1}$ assigned to the $\mathrm{C}=\mathrm{O}$ stretching vibration of conjugated ketone was shifted to $1678 \mathrm{~cm}^{-1}$ after undergoing chemical activation (Fig. 7(b)) but was left unchanged after bio-activation(Fig. 6(b)). The absorption peak at $1603 \mathrm{~cm}^{-1}$ assigned to the $\mathrm{C}=\mathrm{C}$ stretching vibration of conjugated alkene was shifted to 1621 and $1645 \mathrm{~cm}^{-1}$ after bio-activation and chemical activation respectively.

Other important noticeable bands in the carbonized rice husk (Fig. 6(a) and $7(a))$ are $1409 \mathrm{~cm}^{-1}$ (assigned to $\mathrm{C}-\mathrm{H}$ out of plane bending vibration),
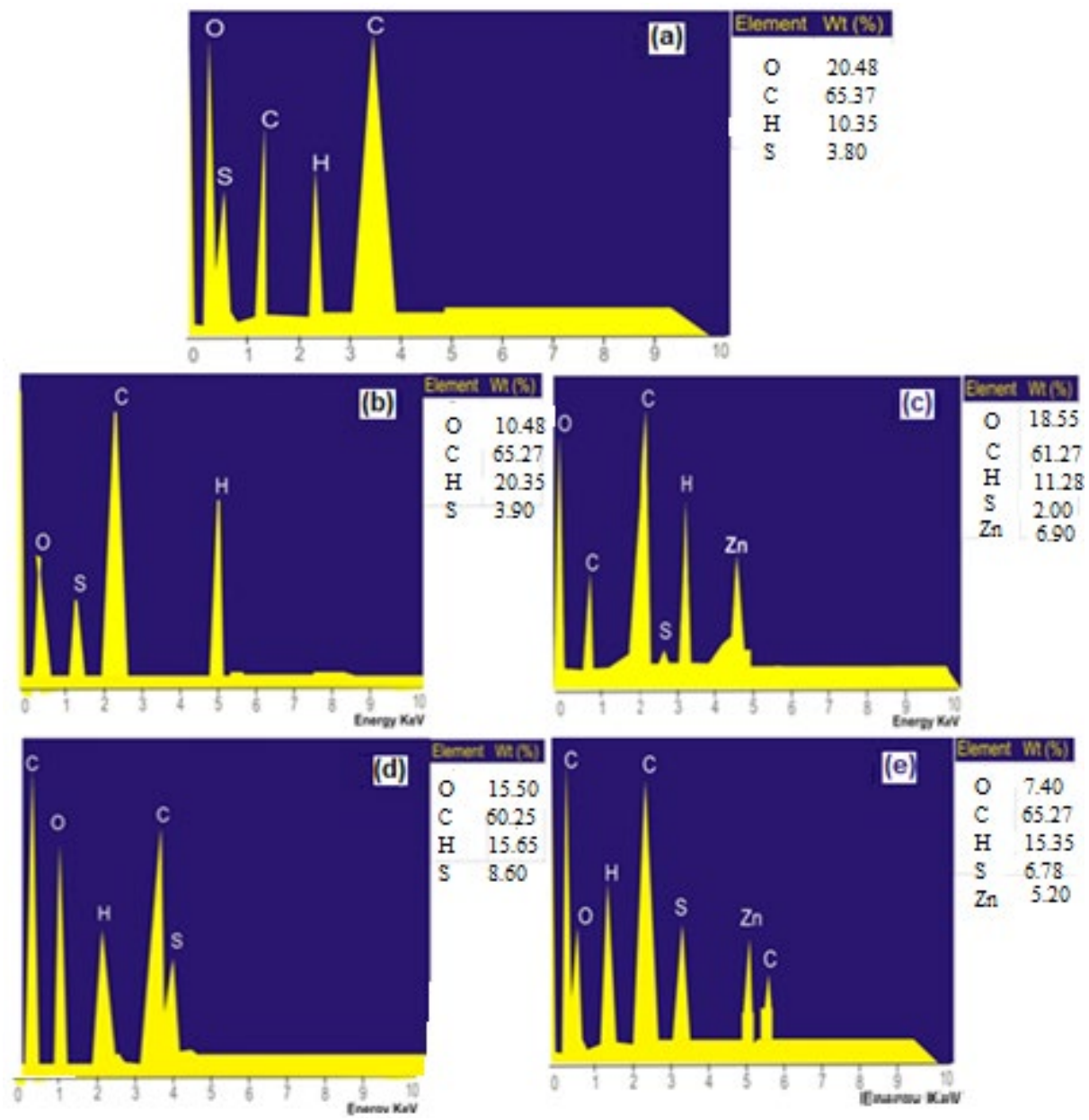

Fig 5. EDX results of: inactivated carbonized rice husk (a); RHAC1 before (b) and after Zn adsorption (c); RHAC2 before (d) and after $\mathrm{Zn}(\mathrm{II})$ adsorption (e) 


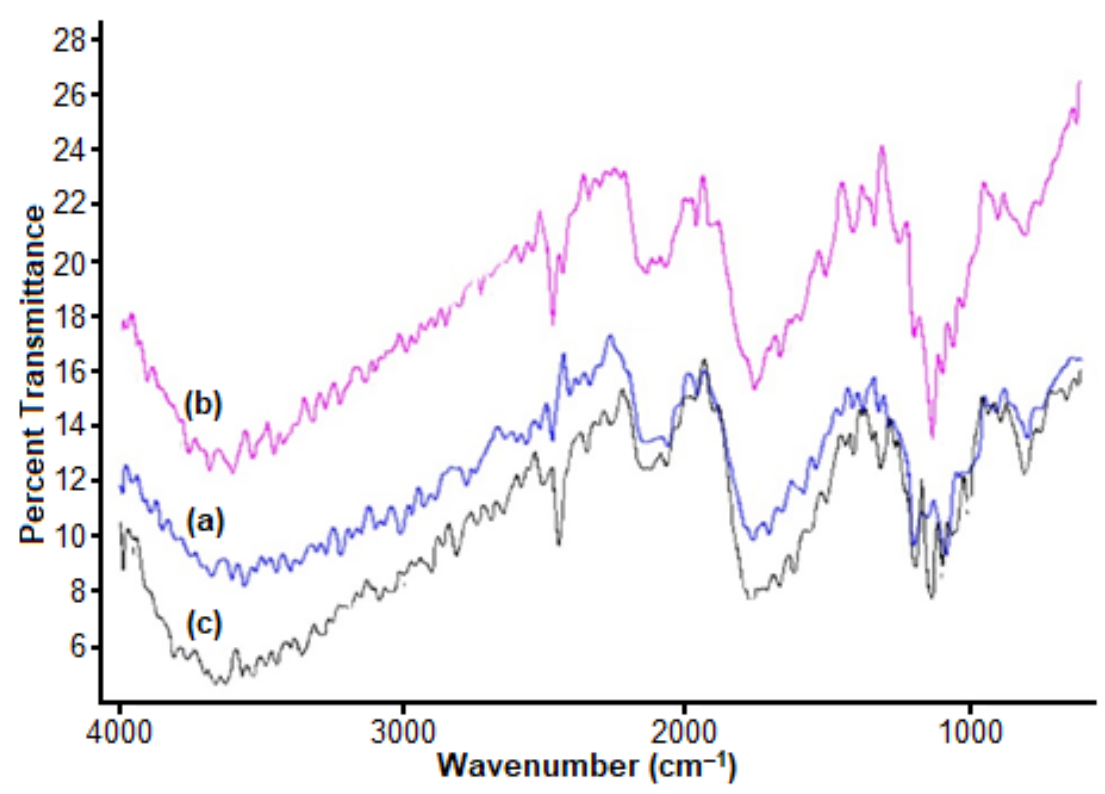

Fig 6. FTIR spectra of: (a) inactivated carbonized rice husk, (b) RHAC1, and (c) RHAC1 after Zn(II) adsorption

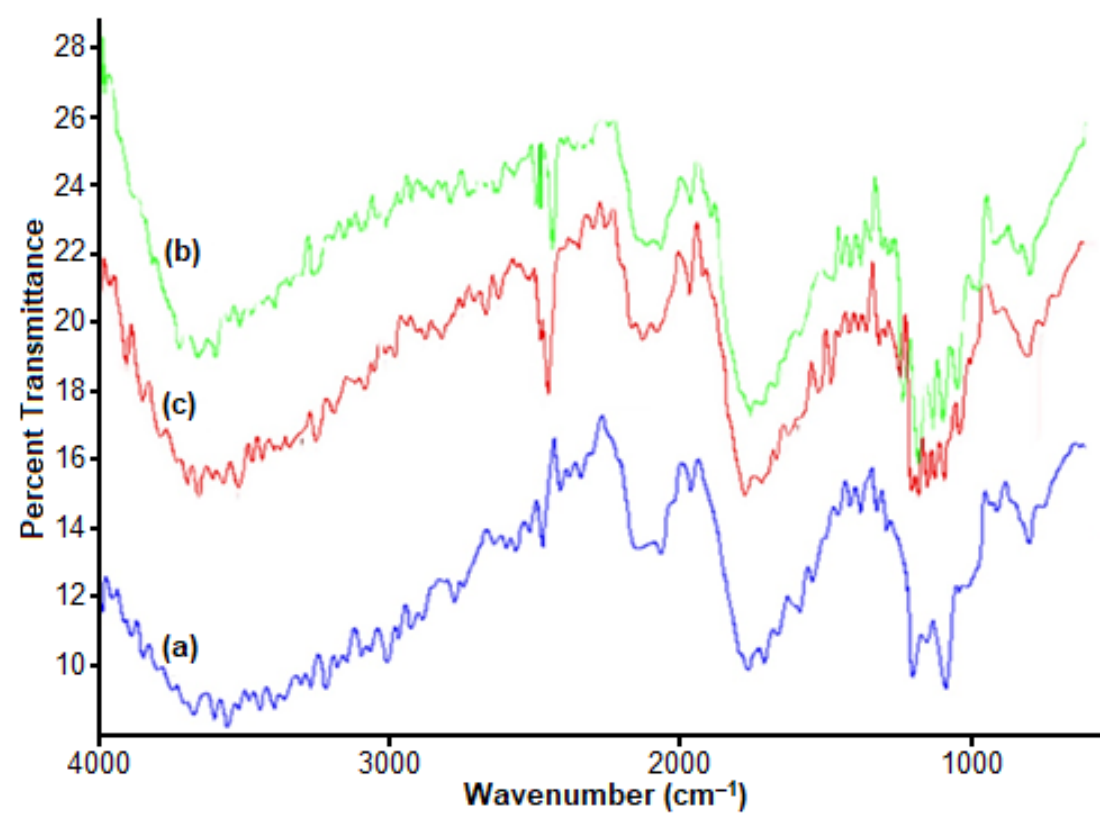

Fig 7. FTIR spectra of: (a) inactivated carbonized rice husk, (b) RHAC2, and (c) RHAC2 after Zn adsorption

$1317 \mathrm{~cm}^{-1}$ (assigned to $\mathrm{OH}$ bending vibration of primary or secondary alcohol) and $1080 \mathrm{~cm}^{-1}$ (assigned to $\mathrm{C}-\mathrm{O}$ stretching of alkyl substituted ether).

All these absorption peaks were also shifted after bio-activation and chemical activation. The changes observed in absorption peaks are a pointer to the influence of both bio-activation and chemical activation on the functional groups at the surface of carbonized rice husk.
For RHAC1, the band at 3458 and $2882 \mathrm{~cm}^{-1}$ (Fig. 6(b)) decreased to 3449 and $2862 \mathrm{~cm}^{-1}$ (Fig. 6(c)) respectively after $\mathrm{Zn}$ (II) adsorption, while the bands at 3276 and $3223 \mathrm{~cm}^{-1}$ (Fig. 6(b)) increased to 3286 and $3251 \mathrm{~cm}^{-1}$, respectively after $\mathrm{Zn}(\mathrm{II})$ adsorption (Fig. 6(c)). This phenomenon, coupled with the appearance of a new vibrational band at $3486 \mathrm{~cm}^{-1}$ revealed that the functional groups on the surface of RHAC1, particularly hydroxyl group, played a prominent role in the 
adsorption of zinc by the bitter leaf extract activated carbon from rice husk. For RHAC2, hydroxyl and carbonyl functional groups played a vital role in its adsorption of $\mathrm{Zn}(\mathrm{II})$ as reflected in the pronounced shifts observed in the absorption peaks of these groups after $\mathrm{Zn}$ (II) adsorption.

\section{Adsorption Thermodynamics}

Temperature has two major effects on adsorption processes. Increase in temperature brings about increase in the rate of diffusion of adsorbate molecules across the external boundary layer and in the internal pores of the adsorbent particles. This can be attributed to the decrease in the viscosity of the solution. In addition, changing the temperature will change the equilibrium capacity of the adsorbent for a particular adsorbate [40]. The thermodynamic parameters of the adsorption of $\mathrm{Zn}$ (II) by RHAC1 and RHAC2 were determined using the following equations:

$\Delta \mathrm{G}^{\circ}=-\mathrm{RT} \ln \mathrm{K}_{\mathrm{e}}$

where $\mathrm{R}$ is the gas constant, $\mathrm{T}$ is the temperature in $\mathrm{K}$ and $\mathrm{K}_{\mathrm{e}}$ is the equilibrium constant given by Eq. (4) [41-43].

$\mathrm{K}_{\mathrm{e}}=-\frac{\mathrm{C}_{\mathrm{e}}-\mathrm{C}_{\mathrm{i}}}{\mathrm{C}_{\mathrm{e}}}$

According to Van't Hoff equation,

$\log _{10} K_{e}=\frac{\Delta S}{2.303 R}-\frac{\Delta H}{2.303 R T}$

The values of $\Delta \mathrm{H}^{\circ}$ and $\Delta \mathrm{S}^{\circ}$ were obtained from the slope and intercept of the plot of $\log \mathrm{K}_{\mathrm{e}}$ against 1/T while values of $\Delta \mathrm{G}^{\circ}$ at different temperatures were obtained using the equation:

$\Delta \mathrm{G}^{\circ}=\Delta \mathrm{H}^{\circ}-\mathrm{T} \Delta \mathrm{S}^{\circ}$
The results of these parameters are presented in Table 1. The positive values of $\Delta \mathrm{H}^{\circ}$ for both RHACl and RHAC2 show that the adsorption process was endothermic while the positive $\Delta S^{\circ}$ values evaluated for both adsorbents suggest increased randomness at the solid/solution interface during the adsorption of $\mathrm{Zn}$ (II) by both activated carbons from rice husk. The values of evaluated Gibbs free energy change for both RHAC1 and RHAC2 were all negative at all temperatures considered. This is an indication of the spontaneity and feasibility of the adsorption process.

\section{Adsorption Kinetic Study}

The adsorption kinetics for RHAC1-Zn(II) and RHAC2-Zn(II) systems was studied using four kinetic models: pseudo first-order, pseudo-second-order, Elovich, and intra-particle models in their natural nonlinear forms. The nonlinear forms were applied because the transformation of nonlinear equations to linear forms, as commonly practiced in most literature reports, may produce bias such as having poor linearity despite high linear regression coefficients, alter their error structure and may also violate the error variance and normality assumptions of standard least-squares method or distort the fit. In addition, linearization can lead to the introduction of error into the independent variable, and alteration of the weight placed on each data point, which often leads to differences in the fitted parameter values between linear and nonlinear versions [44-47].

The pseudo-first-order and pseudo-second-order kinetic models are as presented in Eq. (7) and (8) respectively [48].

Table 1. Thermodynamic parameters for the adsorption of $\mathrm{Zn}(\mathrm{II}) \mathrm{RHAC} 1$ and RHAC2

\begin{tabular}{lcccc}
\hline Sample & $\mathrm{T}(\mathrm{K})$ & $\Delta \mathrm{G}^{\circ}\left(\mathrm{kJ} \mathrm{mol}^{-1}\right)$ & $\Delta \mathrm{H}^{\circ}\left(\mathrm{kJ} \mathrm{mol}^{-1}\right)$ & $\Delta \mathrm{S}^{\circ}\left(\mathrm{kJ} \mathrm{K}^{-1} \mathrm{~mol}^{-1}\right)$ \\
\hline RHAC1 & 298 & -8.80 & 5.36 & 0.475 \\
& 303 & -9.03 & & \\
& 313 & -9.51 & & \\
& 323 & -9.98 & & 0.434 \\
RHAC2 & 298 & -7.08 & 5.97 & \\
& 303 & -7.30 & & \\
& 313 & -7.74 & & \\
& 323 & -8.18 & & \\
\hline
\end{tabular}


$\mathrm{q}_{\mathrm{t}}=\mathrm{q}_{\mathrm{e}}\left[1-\operatorname{Exp}^{\left(-\mathrm{k}_{1} \mathrm{t}\right)}\right]$

$\mathrm{q}_{\mathrm{t}}=\mathrm{q}_{\mathrm{e}}\left[1-\frac{1}{1+\mathrm{q}_{\mathrm{e}} \mathrm{k}_{2} \mathrm{t}}\right]$

where $\mathrm{q}_{\mathrm{e}}$ is the amount of solute adsorbed at equilibrium $\left(\mathrm{mg} \mathrm{g}^{-1}\right), \mathrm{q}_{\mathrm{t}}$ is the amount of solute adsorbed at time $\mathrm{t}(\mathrm{mg}$ $\left.\mathrm{g}^{-1}\right) ; \mathrm{k}_{1}$ is the pseudo-first order equilibrium rate constant $\left(\min ^{-1}\right)$ and $\mathrm{k}_{2}$ is the pseudo-second order equilibrium rate constant $\left(\mathrm{g} \mathrm{mg}^{-1} \mathrm{~min}^{-1}\right)$.

The Elovich's equation, which has been used to describe the kinetics of chemisorption of gases and metal ions onto solid materials [48-49] takes the non-linear form:

$\mathrm{q}=\frac{1}{\beta} \ln (\alpha \beta \mathrm{t}+1)$

where $\alpha$ and $\beta$ are constants. The parameter $\alpha$ represents the rate of chemisorption at zero coverage, the parameter $\beta$ is related to the extent of surface coverage and to the activation energy for the adsorption.

$\mathrm{q}_{\mathrm{t}}=\mathrm{k}_{1} \mathrm{t}^{0.5}+\mathrm{C}$

where $k_{d}$ is the initial rate of intra particular diffusion (mg $\mathrm{L}^{-1} \min ^{-1}$ ), and $\mathrm{C}$ is a constant which is related to the mass transfer across the boundary layer.

The best fitting kinetic model was chosen based on the values of the correlation coefficient $\left(R^{2}\right)$ and the error function. The model that presented the highest $\mathrm{R}^{2}$ value and the lowest $E$ value was adjudged to best fit the data. The sum of the squares of the error (ERRSQ) and the sum of the absolute errors (EABS) were employed to minimize the error distribution between the experimental data (for both kinetics and equilibrium isotherm) and those predicted by the different models using the solver add-in function, Microsoft Excel, Microsoft Corporation.

ERRSQ $=\sum_{\mathrm{i}=1}^{\mathrm{n}}\left(\mathrm{q}_{\mathrm{e} \text { cal }}-\mathrm{q}_{\mathrm{e} \exp }\right)^{2}$

$\mathrm{EABS}=\sum_{\mathrm{i}=1}^{\mathrm{n}}\left|\mathrm{q}_{\mathrm{e} \text { cal }}-\mathrm{q}_{\mathrm{e} \exp }\right|$

where $\mathrm{q}_{\mathrm{e} \text { cal }}$ is each value of $\mathrm{q}$ predicted by the fitted model and $\mathrm{q}_{\mathrm{e} \text { exp }}$ is each value of $\mathrm{q}$ measured experimentally, and $\mathrm{n}$ is the number of experiments performed.

From the $\mathrm{R}^{2}$ and ERRSQ values presented in Table 2, it can be observed that Elovich equation best fitted the adsorption of $\mathrm{Zn}$ (II) by both RHAC1 and RHAC2. This implies that chemisorption played a vital role in the $\mathrm{Zn}$ (II) adsorption by activated carbon from rice husk. Literature reports have indicated that Elovich equation is satisfactory in chemical adsorption processes and is suitable for systems with heterogeneous adsorbing surfaces, thus describing many heavy metal adsorption systems $[45,50]$.

\section{Adsorption Isotherms}

Equilibrium isotherm data are important to develop an equation that can represent results and for design purposes. The equilibrium data obtained at different initial concentrations of $\mathrm{Zn}$ (II) in this study were analyzed using three isotherm models in their nonlinear forms, namely, Langmuir, Freundlich, and Dubinin-Radushkevich as represented by Eq. (13-15) respectively.

Table 2. Kinetics parameters for the adsorption of $\mathrm{Zn}$ (II) by RHAC1 and RHAC2 at $298 \mathrm{~K}$

\begin{tabular}{|c|c|c|}
\hline & RHAC1 & RHAC2 \\
\hline \multicolumn{3}{|l|}{ Pseudo-first-order } \\
\hline $\mathrm{q}_{\mathrm{e}(}\left(\mathrm{mg} \mathrm{g}^{-1}\right)$ & 9.76 & 9.78 \\
\hline $\mathrm{K}_{1}\left(\mathrm{~min}^{-1}\right)$ & 0.77 & 1.01 \\
\hline $\mathrm{R}^{2}$ & 0.7779 & 0.7252 \\
\hline ERRSQ & 12.35 & 33.38 \\
\hline EABS & 5.52 & 12.21 \\
\hline \multicolumn{3}{|c|}{ Pseudo-second- order } \\
\hline $\mathrm{q}_{\mathrm{e}}\left(\mathrm{mg} \mathrm{g}^{-1}\right)$ & 9.39 & 9.84 \\
\hline $\mathrm{K}_{2}\left(\mathrm{~g} \mathrm{mg}^{-1} \mathrm{~min}^{-1}\right)$ & 0.13 & 0.03 \\
\hline $\mathrm{R}^{2}$ & 0.9139 & 0.9622 \\
\hline ERRSQ & 4.03 & 5.18 \\
\hline EABS & 4.82 & 3.91 \\
\hline \multicolumn{3}{|l|}{ Elovich } \\
\hline$a\left(\times 10^{2}\right)$ & 2.37 & 0.40 \\
\hline$\beta$ & 1.05 & 0.88 \\
\hline $\mathrm{R}^{2}$ & 0.9596 & 0.9869 \\
\hline ERRSQ & 2.01 & 0.89 \\
\hline EABS & 3.13 & 1.94 \\
\hline \multicolumn{3}{|l|}{ Intra-particle } \\
\hline $\mathrm{Kd}\left(\mathrm{mg} \mathrm{g}^{-1} \min ^{-0.5}\right)$ & 0.31 & 0.35 \\
\hline $\mathrm{C}$ & 6.39 & 5.63 \\
\hline $\mathrm{R}$ & 0.8257 & 0.9012 \\
\hline ERRSQ & 7.39 & 7.14 \\
\hline EABS & 6.22 & 5.79 \\
\hline
\end{tabular}


$\mathrm{q}=\frac{\mathrm{q}_{\mathrm{m}} \mathrm{K}_{\mathrm{L}} \mathrm{C}_{\mathrm{e}}}{1+\mathrm{K}_{\mathrm{L}} \mathrm{C}_{\mathrm{e}}}$

$\mathrm{q}=\mathrm{K}_{\mathrm{f}} \mathrm{C}_{\mathrm{e}}^{1 / \mathrm{n}}$

$q=q_{D} \operatorname{Exp}\left[-K\left(R T \ln \left(1+\frac{1}{C_{e}}\right)^{2}\right]\right.$

where $\mathrm{q}$ is the $\mathrm{Zn}$ (II) uptake ( $\mathrm{mg} \mathrm{g}^{-1}$ ), $\mathrm{C}_{\mathrm{e}}$ is the equilibrium solute concentration, $\mathrm{q}_{\mathrm{m}}$ is a constant which denotes the maximum achievable uptake by a system $\left(\mathrm{mg} \mathrm{g}^{-1}\right), \mathrm{K}_{\mathrm{L}}$ is the Langmuir constant which defines the affinity between the adsorbate and the adsorbent $\left(\mathrm{L} \mathrm{mg}^{-1}\right), \mathrm{K}_{\mathrm{f}}$ is the Freundlich constant which corresponds to the binding capacity $\left(\mathrm{L}^{1 / \mathrm{n}} \mathrm{g}^{-1} \mathrm{mg}^{-1 / \mathrm{n}}\right), \mathrm{n}$ which characterizes the affinity between the sorbent and adsorbate, $\mathrm{q}_{\mathrm{D}}$ is the DubininRadushkevich model uptake capacity, $\mathrm{K}$ is the DubininRadushkevich model constant $\left(\mathrm{mol}^{2} \mathrm{~kJ}^{-2}\right), \mathrm{R}$ is the gas constant $\left(\mathrm{kJ} \mathrm{K}^{-1} \mathrm{~mol}^{-1}\right)$, and $\mathrm{T}$ is the temperature $(\mathrm{K})$.

The mean adsorption energy can be determined from the D-R model using the following relationship.

$\mathrm{E}=\left(-2 \mathrm{~K}_{\mathrm{D}}\right)^{-1 / 2}$

The results of the adsorption isotherms are presented in Table 3. It can be observed that the adsorption process was best described by the Freundlich model based on the $\mathrm{R}^{2}$ and the error function values. This shows that the adsorption process was largely multi- layered and the system was heterogeneous. According to the Freundlich theory, the adsorption isotherm becomes linear when $\mathrm{n}=1$, favorable when $\mathrm{n}<1$, and unfavorable when $\mathrm{n}>1$ [47]; hence the adsorption of $\mathrm{Zn}(\mathrm{II})$ by both RHAC1 and RHAC2 can be described as favorable. The

Table 3. Isotherm parameters for the adsorption of $\mathrm{Zn}(\mathrm{II})$ by RHAC1 and RHAC2 at $298 \mathrm{~K}$

\begin{tabular}{lcc}
\hline & RHAC1 & RHAC2 \\
\hline Langmuir & & \\
$\mathrm{q}_{\mathrm{m}}\left(\mathrm{mg} \mathrm{g}^{-1}\right)$ & 71.47 & 67.12 \\
$\mathrm{~K}_{\mathrm{L}}\left(\mathrm{L} \mathrm{mg}^{-1}\right)$ & 0.069 & 0.065 \\
$\mathrm{R}^{2}$ & 0.9649 & 0.9814 \\
ERRSQ & 71.05 & 63.19 \\
EAB & 17.85 & 17.98 \\
Freundlich & & \\
$\mathrm{K}_{\mathrm{f}}\left(\mathrm{L}^{1 / \mathrm{n}} \mathrm{g}^{-1} \mathrm{mg}^{-1 / \mathrm{n}}\right)$ & 3.01 & 3.01 \\
$\mathrm{n}$ & 0.97 & 1.05 \\
$\mathrm{R}^{2}$ & 0.9793 & 0.9876 \\
ERRSQ & 55.35 & 25.01 \\
EABS & 8.12 & 7.23 \\
Dubini-Raduskevich & & \\
$\mathrm{q}_{\mathrm{D}}\left(\mathrm{mg} \mathrm{g}^{-1}\right)$ & 29.29 & 28.42 \\
$\mathrm{E}(\mathrm{kJ} \mathrm{mol}$ & \\
$\mathrm{R}^{2}$ & 0.62 & 0.59 \\
ERRSQ & 0.9188 & 0.9341 \\
EABS & 198.24 & 133.57 \\
\hline
\end{tabular}

Table 4. Comparison of maximum adsorption capacity of RHAC1 and RHAC2 for Zn(II) with some other activated carbons reported in literature

\begin{tabular}{llcc}
\hline S/N & Activated Carbon Precursor & $\mathrm{q}_{\max }\left(\mathrm{mg} \mathrm{g}^{-1}\right)$ & Reference \\
\hline 1. & Mesembryanthemum & 52.63 & {$[16]$} \\
2. & Olive stone waste & 18.95 & {$[17]$} \\
3. & Nigerian bamboo & 250 & {$[18]$} \\
4 & Xanthoceras sorbifolia Bunge hull & 100.7 & {$[19]$} \\
5. & Eucalyptus seeds & 80.37 & {$[20]$} \\
6. & Olive branches & 34.97 & {$[21]$} \\
7. & Birch saw dust & 21.44 & {$[22]$} \\
8. & Dates stone & 10.41 & {$[38]$} \\
9. & Capsicum straw & 63.3 & {$[39]$} \\
10. & Treated green coconut (Cocos nucifera) shells & 17.08 & {$[46]$} \\
11. & Commercial activated carbon & 19.9 & {$[46]$} \\
12 & Date pit & 111 & {$[51]$} \\
13 & RHAC1 & 71.47 & This study \\
14 & RHAC2 & 67.12 & This study \\
\hline
\end{tabular}


mean adsorption energy (E) value for the adsorption of $\mathrm{Zn}$ (II) on both RHAC1 and RHAC2 fell within the range $(<8 \mathrm{~kJ})$ for physical adsorption. This indicates that physisorption also played some part in the adsorption process.

A comparison of the Langmuir maximum adsorption capacities of RHAC1 and RHAC2 with other activated carbon from other precursors presented in Table 4 indicates that the maximum adsorption capacity values evaluated in this study compare favorably with those previously reported in literature.

\section{- CONCLUSION}

It is practicable and feasible to activate carbonized rice husk with aqueous bitter leaf extract and still obtain a similar or slightly better result than activation using conventional but toxic and non-eco-friendly chemical activating agents $\left(\mathrm{H}_{2} \mathrm{SO}_{4}\right)$. This study revealed that bitter leaf extract activated rice husk carbon and its $\mathrm{H}_{2} \mathrm{SO}_{4}$ activated counterpart had a more porous and finer surface than the inactivated carbonized rice husk. The study further showed that the adsorption of $\mathrm{Zn}$ (II) from aqueous solution by the two activated carbon types was temperature, $\mathrm{pH}$, contact time, and adsorbent dosage dependent. The removal of $\mathrm{Zn}$ (II) by both activated carbons was spontaneous, feasible, and endothermic. The kinetic evaluation showed that the process followed the Elovich kinetic model while the isotherm parameter analysis showed that the adsorption process followed the Freundlich isotherm model and had Langmuir maximum adsorption capacity of 71.47 (RHAC1) and $67.12 \mathrm{mg} \mathrm{g}^{-1}$ (RHAC2).

\section{- REFERENCES}

[1] Osasona, I., Ajayi, O.O., and Adebayo, A.O., 2013, Equilibrium, kinetics, and thermodynamics of the biosorption of $\mathrm{Zn}$ (II) from aqueous solution using powdered cow hooves, Int. Sch. Res. Notices, 2013, 865219.

[2] Lakherwal, D., 2014, Adsorption of heavy metals: A review, Int. J. Environ. Res. Dev., 4 (1), 41-48.

[3] Ajjabi, L.C., and Chouba, L., 2009, Biosorption of $\mathrm{Cu}^{2+}$ and $\mathrm{Zn}^{2+}$ from aqueous solutions by dried marine green macroalga Chaetomorpha linum, J. Environ. Manage., 90 (11), 3485-3489.

[4] Engelking, L.R., 2015, "Zinc" in Textbook of Veterinary Physiological Chemistry, $3^{\text {rd }}$ Ed., Academic Press, Boston, US, 309-313.

[5] Volesky, B., and Holan, Z.R., 1995, Biosorption of heavy metals, Biotechnol. Progr., 11 (3), 235-250.

[6] Plum, L.M., Rink, L., and Haase, H., 2010, Essential toxin: Impact of zinc on human health, Int. J. Environ. Res Public Health, 7 (4), 1342-1365.

[7] Nomanbhay, S.M., and Palanisamy, K., 2005, Removal of heavy metal from industrial wastewater using chitosan coated oil palm shell charcoal, Electron. J. Biotechnol., 8 (1), 43-53.

[8] Monser, L., and Adhoum, N., 2002, Modified activated carbon for the removal of copper, zinc, chromium, and cyanide from wastewater, Sep. Purif. Technol., 26 (2-3), 137-146.

[9] Shim, J.W., Park, S.J., and Ryu, S.K., 2001, Effect of modification with $\mathrm{HNO}_{3}$ and $\mathrm{NaOH}$ on metal adsorption by pitch-based activated carbon fibers, Carbon, 39 (11), 1635-1642.

[10] Ismail, N.E.A., Taha, M.F., and Ramli, A., 2016, Preparation and characterization activated carbon from rice husk and oil palm empty fruit bunches for removal of $\mathrm{Zn}^{2+}$ in aqueous solution, AIC Conf. Proc., 1787, 040019.

[11] Osasona, I., Aiyedatiwa, K., Johnson, J.A., and Faboya O.L., 2018, Activated carbon from spent brewery barley husks for cadmium ion adsorption from aqueous solution, Indones. J. Chem., 18 (1), $145-152$.

[12] Li, K., and Wang, X., 2009, Adsorptive removal of $\mathrm{Pb}$ (II) by activated carbon prepared from Spartina alterniflora: Equilibrium, kinetics and thermodynamics, Bioresour. Technol., 100 (11), 2810-2815.

[13] Hasar, H., Cuci, Y., Obek, E., and Dilekoglu, M.F., 2003, Removal of zinc(II) by activated carbon prepared from almond husks under different conditions, Adsorpt. Sci. Technol., 21 (9), 799-808.

[14] Kobya, M., Demirbas, E., Senturk, E., and Ince, M., 2005, Adsorption of heavy metal ions from aqueous 
solutions by activated carbon prepared from apricot stone, Bioresour. Technol., 96 (13), 1518-1521.

[15] Amuda, O.S., Giwa, A.A., and Bello, I.A., 2007, Removal of heavy metal from industrial wastewater using modified activated coconut shell carbon, Biochem. Eng. J., 36 (2), 174-181.

[16] Alkherraz, A.M., Ali, A.K., and Elsherif, K.M., 2020, Equilibrium and thermodynamic studies of $\mathrm{Pb}(\mathrm{II})$, $\mathrm{Zn}(\mathrm{II}), \quad \mathrm{Cu}(\mathrm{II})$ and $\mathrm{Cd}(\mathrm{II})$ adsorption onto mesembryanthemum activated carbon, J. Med. Chem. Sci., 3, 1-10.

[17] Sharaf El-Deen, G.E, 2015, Sorption of Cu(II), Zn(II) and $\mathrm{Ni}$ (II) from aqueous solution using activated carbon prepared from olive stone waste, $A d v$. Environ. Technol., 3, 147-161.

[18] Ademiluyi, F.T., and Abidde, A., 2016, Batch adsorption kinetics of zinc ions using activated carbon from waste Nigerian bamboo, Int. J. Eng. Appl. Sci., 3 (1), 95-99.

[19] Zhang, X., Hao, Y., Wang, X., and Chen, Z., 2017, Rapid removal of Zinc(II) from aqueous solutions using a mesoporous activated carbon prepared from agricultural waste, Materials, 10 (9), 1002.

[20] Kumar, P.S., Saravanan, A., Kumar, K.A., Yashwanth, R., and Visvesh, S., 2016, Removal of toxic zinc from water/wastewater using eucalyptus seeds activated carbon: Non-linear regression analysis, IET Nanobiotechnol., 10 (4), 244-253.

[21] Alkherraz, A.M., Ali, A.K., and Elsherif, K.M., 2020, Removal of $\mathrm{Pb}(\mathrm{II}), \mathrm{Zn}(\mathrm{II}), \mathrm{Cu}(\mathrm{II})$ and $\mathrm{Cd}(\mathrm{II})$ from aqueous solutions by adsorption onto olive branches activated carbon: Equilibrium and thermodynamic studies, Chem. Int., 6 (1), 11-20.

[22] Tuomikoski, S., Kupila, R., Romar, H., Bergna, D., Kangas, T., Runtti, H., and Lassi, U., 2019, Zinc adsorption by activated carbon prepared from lignocellulosic waste biomass, Appl. Sci., 9 (21), 4853.

[23] Adebisi, G.A., Chowdhury, Z.Z., and Alaba, P.A., 2017, Equilibrium, kinetic, and thermodynamic studies of lead ion and zinc ion adsorption from aqueous solution onto activated carbon prepared from palm oil mill effluent, J. Cleaner Prod., 148, 958-968.
[24] Ajala, A.S., and Gana, A., 2015, Analysis of challenges facing rice processing in Nigeria, J. Food Process., 2015, 893673.

[25] James, A., Mamai, E.A., and Bako, T., 2017, Rice waste conversion for economic empowerment in Taraba State, Nigeria: A review, Int. J. Trend Res. Dev., 4 (5), 515-519.

[26] Abass, A., and Ansumali, S., 2010, Global potential of rice husk as a renewable feedstock for ethanol biofuel production, BioEnergy Res., 3 (4), 328-334.

[27] Okoro, E.E., Dosunmu, A., Iyuke, S., and Oriji, B., 2016, Production of silicon ethoxide from Nigerian rice husk, Int. J. Recent Sci. Res., 7 (2), 9032-9036.

[28] Faronmbi, E.O., and Owoeye, O., 2011, Antioxidative and chemopreventive properties of Vernonia amygdalina and Garcinia biflavonoid, Int. J. Environ. Res. Public Health, 8 (6), 2533-2555.

[29] Alara, O.R., Abdurahman, N.H., Mudalip, S.K.A., and Olalere, O.A., 2017, Phytochemical and pharmacological properties of Vernonia amygdalina: A review, JCEIB, 2 (1), 80-96.

[30] Imaga, N.O.A., and Bamigbetan, D.O., 2013, In vivo biochemical assessment of aqueous extracts of Vernonia amygdalina (Bitter leaf), Int. J. Nutr. Metab., 5 (2), 22-27.

[31] Seef, L.B., Lindsay, K.L., Bacon, B.R., Kresina, T.F., and Hoofnagle, J.H., 2001, Complementary and alternative medicine in chronic liver disease, Hepatology, 34 (3), 595-603.

[32] Ekpete, O.A., Horsfall Jr., M., and Tarawou, T., 2011, Sorption kinetic study on the removal of phenol using fluted pumpkin and commercial activated carbon, Int. J. Biol. Chem. Sci., 5 (3), 1143-1152.

[33] Vijayaraghavan, K., and Yun, Y.S., 2008, Bacterial biosorbents and biosorption, Biotechnol. Adv., 26 (3), 266-291.

[34] Elliott, H.A., and Huang, C.P., 1981, Adsorption characteristics of some $\mathrm{Cu}(\mathrm{II})$ complexes on aluminosilicates, Water Res., 15 (7), 849-855.

[35] Srivastava, V.C., Swamy, M.M., Mall, I.D., Prasad, B., and Mishra, I.M., 2006, Adsorptive removal of phenol by bagasse fly ash and activated carbon: 
Equilibrium, kinetics and thermodynamics, Colloids Surf., A, 272 (1-2), 89-104.

[36] Khademi, Z., Ramavandi, B., and Ghaneian, M.T., 2015, The behaviors and characteristics of a mesoporous activated carbon prepared from Tamarix hispida for $\mathrm{Zn}(\mathrm{II})$ adsorption from wastewater, J. Environ. Chem. Eng., 3 (3), 2057-2067.

[37] Fischer, A.R., Sgolik, L., Kreller, A., and Dornack, C., 2018, Zinc(II) adsorption by low-carbon shungite: The effect of $\mathrm{pH}$, Water, 10 (4), 422.

[38] Mouni, L., Merabet, D., Bouzaza, K., and Belkhiri, L., 2010, Removal of $\mathrm{Pb}^{2+}$ and $\mathrm{Zn}^{2+}$ from the aqueous solutions by activated carbon prepared from Dates stone, Desalin. Water Treat., 16 (1-3), 66-73.

[39] Yang, C., Girma, A., Lei, T., Liu, Y., and Ma, C., 2016, Study on simultaneous adsorption of $\mathrm{Zn}$ (II) and methylene blue on waste-derived activated carbon for efficient applications in wastewater treatment, Cogent Environ. Sci., 2, 1151983.

[40] Sathishkumar, M., Binupriya, A.R., Kavitha D., Selvakumar, R., Choi, J.G., and, Yun, S.E., 2009, Adsorption potential of maize cob carbon for 2,4dichlorophenol removal from aqueous solutions: Equilibrium, kinetics and thermodynamics modeling, Chem. Eng. J., 147 (2-3), 265-271.

[41] Al-Rashed, S.M., and Al-Gaid A.A., 2012, Kinetic and thermodynamic studies on the adsorption behavior of Rhodamine B dye on Duolite C-20 resin, J. Saudi Chem. Soc., 16 (2), 209-215.

[42] Yu, Y., Zhuang, Y.Y., and Wang, Z.H., 2001, Adsorption of water soluble dye onto functionalized resin, J. Colloid Interface Sci., 242 (2), 288-293.

[43] Malik, A., Khan, A., Anwar, N., and Naeem, M., 2020, Comparative study of the adsorption of Congo Red dye on rice husk, rice husk char and chemically modified rice husk char from aqueous media, Bull. Chem. Soc. Ethiop., 34 (1), 41-54.

[44] Foo, K.Y., and Hameed, B.H., 2010, Insights into the modeling of adsorption isotherm systems, Chem. Eng. J., 156 (1), 2-10.
[45] López-Luna, J., Ramírez-Montes, L.E., Martinez-Vargas, S., Martínez, A.I., Mijangos-Ricardez, O.F., González-Chávez, M.C.A., Carrillo-González, R., Solís-Domínguez, F.A., Cuevas-Díaz, M.C., and Vázquez-Hipólito, V., 2019, Linear and nonlinear kinetic and isotherm adsorption models for arsenic removal by manganese ferrite nanoparticles, SN Appl. Sci., 1 (8), 950.

[46] Mahmoud, D.K., Mohd Salleh, M.A., and Wan Abdul Karim, W.A., 2012, Langmuir model application on solid liquid adsorption using agricultural wastes: Environmental application review, J. Purity Util. React. Environ., 1 (4), 170199.

[47] Tran, H.N., You, S.J., Hosseini-Bandegharaei, A., and Chao, H.P., 2017, Mistakes and inconsistencies regarding adsorption of contaminants from aqueous solutions: A critical review, Water Res., 120, 88-116.

[48] Cheung, C.W., Porter, J.F., and McKay, G., 2000, Sorption kinetics for the removal of copper and zinc from effluents using bone char, Sep. Purif. Technol., 19 (1-2), 55-64.

[49] Osasona, I., Adebayo, A.O., and Okoronkwo, A.E., 2017, Characterization and utilization of citric acid modified cow hoof for adsorption of cadmium and copper from wastewater, Chem. Sci. Int. J., 21 (1), 32537.

[50] Wu, F.C., Tseng, R.L., and Juang, R.S., 2009, Characteristics of Elovich equation used for the analysis of adsorption kinetics in dye-chitosan systems, Chem. Eng. J., 150 (2-3), 366-373.

[51] Aldawsari, A., Khan, M.A., Hameed, B.H., Alqadami, A.A., Siddiqui, M.R., Alothman, Z.A., and Hadj Ahmed, A.Y.B., 2017, Mercerized mesoporous date pit activated carbon- A novel adsorbent to sequester potentially toxic divalent heavy metals from water, PLoS ONE, 12 (9), e0184493. 